\title{
Use of methods of cluster analysis in designing strategy of region's agro-food complex
}

\author{
Eugene Stovba \\ Birsk branch of FSBEI HE «Bashkir State University» \\ Birsk branch of BashSU \\ Birsk, Russia \\ stovba2005@rambler.ru
}

Andrey Stovba

Birsk branch of FSBEI HE «Bashkir State University»

Birsk branch of BashSU

Birsk, Russia

stovbaav2006@rambler.ru

\author{
Alfira Abdrashitova \\ Bashkir Cooperative Institute (branch) \\ Russian University of Cooperation \\ BCI (branch) RUC \\ Ufa, Russia \\ Idrisova_alfira@mail.ru
}

\author{
Albina Baygildina \\ Bashkir Cooperative Institute (branch) \\ Russian University of Cooperation \\ BCI (branch) RUC \\ Ufa, Russia \\ Bau78@mail.ru
}

\begin{abstract}
The article substantiates the necessity of using cluster analysis methods in designing the strategy for the development of the agro-food complex at the regional level. A brief analysis of the foreign experience of using the cluster approach in the development of regional strategic planning programs is given. The algorithm of clusterization that allows allocating "reference" and "target" municipal entities of the region, based on indicators reflecting the volumes of production of agro-food products is presented. The results of clustering of municipal entities of the Republic of Bashkortostan by selfsufficiency of the population with basic food products are given. Because of clustering, the "standard" ("leaders") and "target" ("outsiders") municipal formations of the region are defined. Within the formed clusters, municipal formations that have "extreme" values of indicators of the volume of production of basic food products per capita have been identified. The practical significance of the research is that the proposed recommendations make it possible to solve problems on the development of food provision for the population of the region, the use of commodity food resources, and the improvement of inter-municipal food relations.
\end{abstract}

Keywords- cluster analysis; cluster; region; agro-food complex;

\section{INTRODUCTION}

At present, the problem of developing a strategy for the development of the agro-food complex is one of the most important and relevant areas of domestic economic research. When carrying out an assessment of the state of sustainability of the agrarian sector of the economy, the key factor is given to the development of conditions for ensuring regional food security and the long-term forecast development of the agrofood complex at the level of the territorial entities of the Russian Federation [1, 2].

Achieving food security determines the provision of the population with the necessary food products of their own production. The scientific importance of solving issues related to the rational allocation of agricultural production sectors, the development of a strategy for the development of the agro- food complex at the regional level, causes the application of cluster analysis methods.

Today, the understanding of cluster philosophy is growing in the world scientific community, and clusters themselves become a key component of national and regional strategic plans for economic development. For the Russian Federation, one of the most promising areas for increasing competitiveness and implementing an innovation strategy for economic development should be a cluster-oriented policy that takes into account the regional dimension. The cluster approach is one of the most effective tools for assessing the development of the agro-food complex and ensuring regional food security. The formation of agro-food clusters helps to increase the competitiveness of agricultural production, expand the range of food products and improve the food supply of the population.

\section{RESUlTS AND DisCUSSION}

In Russia, the formation of a network of territorial clusters that realize the competitive potential of the territories was declared as one of the strategic goals of the Concept of LongTerm Social and Economic Development of the Russian Federation for the Period to 2020, approved by the RF Government Decree of November 17, 2008 [3]. The application of the cluster approach allows us to realize a consistent transition from the "alignment policy" to the principle of "polarized" ("focused") development of the Russian regions.

The experience of economically developed countries clearly shows that the cluster approach is effectively used in the design of strategic development programs at various hierarchical levels of government $[4,5,6]$. The application of the cluster approach is more effective if the bunched clusters are inscribed in a broader context of the regional economy development strategy. Regions, in which clusters are formed, become leaders in the economic development of the state. Modern economy, based on clusters, allows involving in the

The research was carried out with the financial support of the Russian Foundation for Basic Research and the Republic of Bashkortostan within the framework of the research project "Development of an import substitution strategy in the agro-food complex of the Republic of Bashkortostan in conditions of economic sanctions", project No. 16-12-02004 a / U. 
production process not only large organizations of the region, but also small business enterprises.

In the United States, Canada, Japan, the EU states, formed clusters are an innovative driver, megatrend of modern economy [7, 8]. In the American economy, 380 largest clusters have been created involving $57 \%$ of the country's total labor resources and $61 \%$ of GDP [9, p. 114]. According to the conducted researches in 7 of 19 European regions, on the territory of which clusters are efficiently developing, they are in the top three of innovatively active regions [10].

As world practice shows, clusterization serves not only as an effective means of achieving the goals of agrarian policy, but also as a strategic imperative for the regional development of the agro-food complex. Denmark, as a successful example of the introduction of cluster technologies in agriculture, after the creation of 29 leading agro-industrial clusters became an exporter on the foreign markets, supplying $60 \%$ of agricultural output abroad [11, p. 38].

There is a great deal of articles and monographs devoted to cluster problems published in Russia today, but not enough attention is given to cluster models on the effectiveness of agro-food complex development. At the same time, according to research carried out by experts from Bauman Innovation, about $45 \%$ of employment in our country falls on existing and potential clusters, while the growth and sustainability of this employment will in the long term depend on the further development of clusters [12, p. 138].

The application of methods of cluster analysis determines the rational allocation and optimal use of the existing production potential of agricultural organizations associated with the production of food. As the academician of the Russian Academy of Sciences, E.N. Krilatyth fairly points out: "Cluster analysis allows us to assess the opportunities for ensuring the necessary level of food security, taking into account the resources, the effectiveness of their use, the level of food consumption, the degree of dependence on the international food market" [13, p. 152].

The agro-food complex development strategy on a regional scale can be successfully implemented on the conceptual basis of the theory of "growth poles" of any geographic area (the concept of poles de croissance) according to the French economists F. Perroux and J.-R. Boudeville. It defines a 'pole de croissance' as an industry or group of related industries that have growth rates above the national average level and the capacity to generate growth through the impact of strong input-output linkages.

At the same time, the effective functioning of the innovation model of the development of the regional agrofood complex is based on the application of the cluster approach intended to "level out" and mitigate the negative consequences of the polarization of municipalities. At the same time, interacting in the cluster actors can create positive external effects, which enhance the competitiveness of other cluster subjects [14].

The authors have developed a clustering algorithm that allows one to identify "reference" and "target" municipal entities of the region in the production of agro-food products (fig. 1).

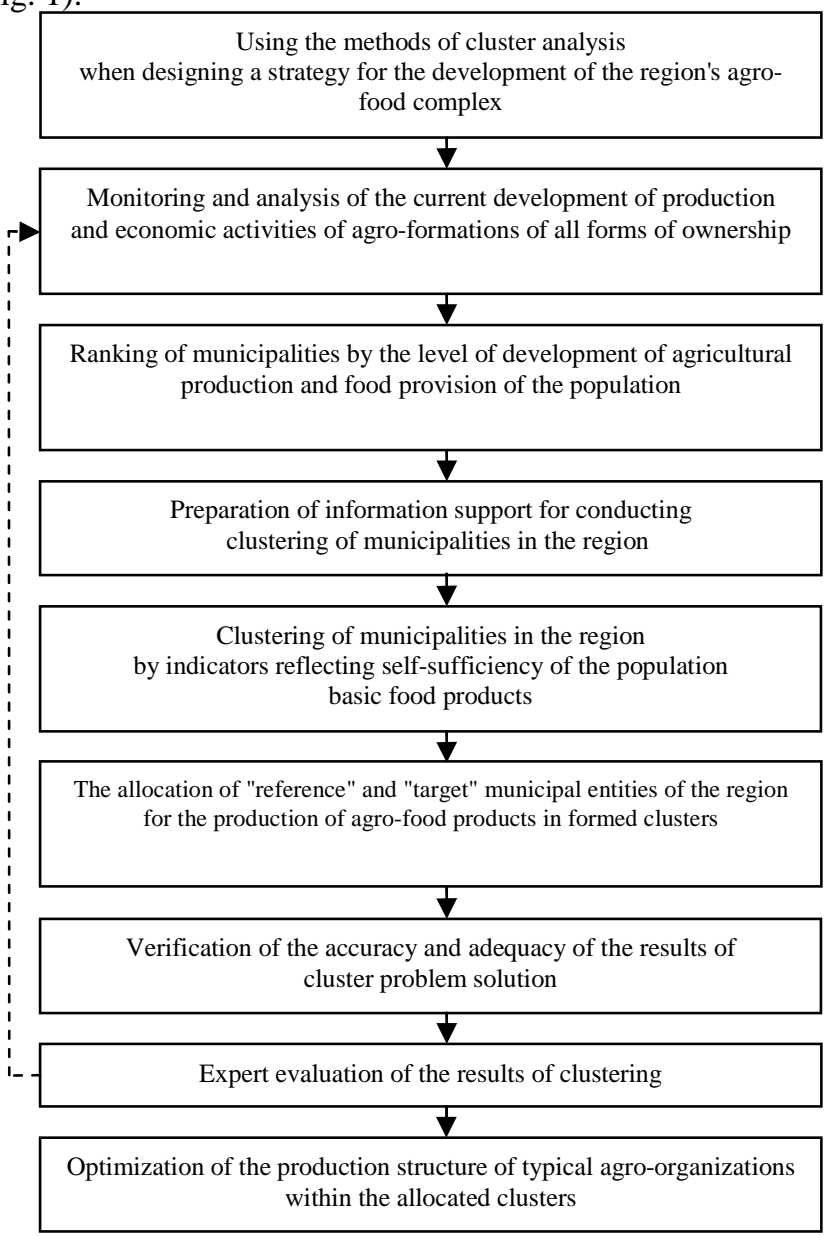

Fig. 1. Algorithm for clustering municipal entities in the production of agrofood products

The use of the cluster approach is of particular interest for the prospects of the development of agriculture, and the provision of food security in such region as the Republic of Bashkortostan. The formation of a new architecture for the functioning of the agro-food complex, based on the development of cluster politics, is a key element of the longterm strategy of the republic economic development.

In 2015, the Republic of Bashkortostan took the second place by the volume of gross agricultural output among the regions of the Volga Federal District, and the seventh place among all regions of the Russian Federation. At the same time, according to statistical data, the share of the agrarian sector of the region in the total output of agricultural production in the country amounted to $2.9 \%$ for grains, $2.6 \%$ for sunflower, $3.3 \%$ - for sugar beets; for vegetables $-2.3 \%$, potatoes $-3.4 \%$, milk $-5.9 \%$, meat $-2.9 \%$, eggs $-2.2 \%$, honey $-8.8 \%[15]$.

During the same period of time, the region took the fifteenth place in terms of the gross volume of sunflower production, the twelfth place for vegetable production, the fifth place for the production of potatoes, the nineteenth place for the production of fruits and berries compared with other territorial entities of the Russian Federation. 
In 2015, the Republic of Bashkortostan took the first place among the territorial entities of the Russian Federation for cattle, the thirteenth place - for pigs, the third place - for the number of horses, the ninth place - for sheep and goats. For the comparative period, the Republic took the first place in terms of the gross production of milk and honey among all the territorial entities of the Russian Federation, the ninth place for meat production, the twentieth place - for eggs production, and the seventh place - for wool production [15].

The problem of achieving the food safety of the Republic has an integral character, since it accumulates key moments of the development of the agrarian sector of the economy, the production of food and agricultural raw materials, the functioning of the food market and the level of its dependence on imported food supplies. Designing a strategy for the development of effective organization of food production determines the formation of a multicluster food regional system.

It should be noted that zonal specialization of agrarian production has actually taken place on the territory of the Republic; however, there are no full-fledged agro-food clusters. At the same time, the region has all the necessary opportunities for the formation and development of agro-food clusters and the existing agro-formations are potentially capable of forming a full-fledged cluster system.

The modern paradigm for the development of the economy of the country causes, to a large extent, the delineation of most municipalities in terms of the level of development of agrofood production and contribution to regional food security. The purpose of clusterization is the grouping of all municipalities in terms of indicators, expressing the selfsufficiency of the city and rural population of the country with agro-food products. The multidimensional classification of the municipal formations of the Republic was carried out taking into account the degree of their participation in the production of the main types of food products.

When carrying out cluster calculations, the following factors were taken into account:

- the actual and projected number of people, residing within each municipality;

- volumes of demand and supply on the regional food market, the level of solvency of the urban and rural population of the Republic.

Clustering was carried out for all 54 municipal entities of the Republic of Bashkortostan (excluding city districts), using statistical indicators for 2005-2015, reflecting the volumes of production of grain, potatoes, vegetables, meat, milk and eggs per capita [5]. The application of methods of cluster analysis has made it possible to group municipal entities that are similar in certain features to the calculation in four homogeneous clusters (table 1).

The subjects included in the clusters were considered as interrelated elements that determine the development of the food market. Let us assess the contribution of each formed cluster to ensuring the food security of the region.
TABLE I. BRIEF CHARACTERISTIC OF FORMED CLUSTERS

\begin{tabular}{|l|c|c|c|c|}
\hline \multirow{2}{*}{ Indicators } & \multicolumn{5}{c|}{ Cluster number } \\
\cline { 2 - 5 } & I & II & III & IV \\
\hline Number of municipalities & 14 & 14 & 24 & 2 \\
\hline Number of rural settlements & 1000 & 1254 & 2043 & 200 \\
\hline Pure rural settlements & 206 & 218 & 355 & 39 \\
\hline Population, thousand people & 485 & 880 & 625 & 121 \\
\hline \multicolumn{5}{|c|}{ Production of agro-food products, per year, thousand tons } \\
\hline Grain & 556 & 423 & 1244 & 193 \\
\hline Vegetables & 42 & 140 & 84 & 46 \\
\hline Potatoes & 196 & 365 & 478 & 83 \\
\hline Milk & 456 & 403 & 812 & 94 \\
\hline Meat & 83 & 47 & 94 & 26 \\
\hline Egg, mln. pcs & 95 & 22 & 14 & 58 \\
\hline \multicolumn{7}{|c|}{ Production of agro-food products per capita per year, kg } \\
\hline Grain & 1130 & 572 & 1961 & 2102 \\
\hline Vegetables & 90 & 146 & 133 & 419 \\
\hline Potatoes & 470 & 498 & 769 & 740 \\
\hline Milk & 1087 & 541 & 1311 & 996 \\
\hline Meat & 158 & 63 & 153 & 237 \\
\hline Egg. Pcs & 212 & 203 & 223 & 4738 \\
\hline
\end{tabular}

The first cluster includes fourteen municipalities that are characterized by average performance and tend to underutilize the existing clustering potential to ensure the tasks of regional food security. $23 \%$ of the population live in these municipalities. Agroforming of this cluster produces $23 \%$ of grain, $17 \%$ of potatoes, $13 \%$ of vegetables, $33 \%$ of meat, $26 \%$ of milk and $9 \%$ of eggs from the regional volume of corresponding types of agro-food products. When compared with the second and third clusters, the production of potatoes and vegetables (per capita) is lower.

The second cluster is represented by fourteen municipalities that have reserves in the production of agrofood products. $42 \%$ of the region's population live on the territory of the cluster, producing $17 \%$ of grain, $32 \%$ of potatoes, $45 \%$ of vegetables, $19 \%$ of meat, $23 \%$ of milk and $21 \%$ of eggs from regional volume of relevant agro-food products. In this cluster, there are lower indicators, reflecting the volumes of production of grain, meat, milk and eggs (per capita), compared to the first and third clusters.

The third cluster includes twenty-four municipalities of the region, which are characterized by stable and dynamic development of agro-food production. $29 \%$ of the population live on the territory of the formed cluster. The total share of agro-formations of this cluster in the total volume of the region's products is: grain - $52 \%$, potatoes $-43 \%$, vegetables $27 \%$, meat - 38\%, milk - 46\%, eggs - 14\%. These municipalities have the greatest potential for clustering, they have the highest rates of production of agro-food products (per capita) in comparison with the municipalities of other clusters.

The fourth cluster consists of two municipalities, in which $6 \%$ of the region's inhabitants live, producing $8 \%$ of grain, $7 \%$ of potatoes, $15 \%$ of vegetables, $10 \%$ of meat, $5 \%$ of milk and $56 \%$ of eggs from regional volume of produced agro-food products. According to the clustering, the municipalities that form this cluster differ significantly from the municipalities of other clusters according to the selected indicators. As part of the study, the authors have identified the municipalities in the region that have "extreme" - the minimum and maximum values of the output of agro-food products per capita per year (table 2, 3). 
TABLE II. EXTREME VALUES OF INDICATORS OF CROP PRODUCTION FOR FORMED CLUSTERS

\begin{tabular}{|c|c|c|c|}
\hline $\begin{array}{l}\text { Cluster } \\
\text { number }\end{array}$ & \multicolumn{2}{|l|}{ Indicators } & $\begin{array}{c}\text { Municipal } \\
\text { entity }\end{array}$ \\
\hline \multicolumn{4}{|c|}{ Production of grain per capita per year, $\mathrm{kg}$} \\
\hline \multirow{2}{*}{$\begin{array}{c}\text { I } \\
\text { cluster }\end{array}$} & minimum value & 11 & Burzyansky district \\
\hline & maximum value & 4390 & Fedorov district \\
\hline \multirow{2}{*}{$\begin{array}{c}\text { II } \\
\text { cluster }\end{array}$} & minimum value & 11 & Beloretsky district \\
\hline & maximum value & 1583 & Chishminsky district \\
\hline \multirow{2}{*}{$\begin{array}{c}\text { III } \\
\text { cluster }\end{array}$} & minimum value & 327 & Arkhangelsky District \\
\hline & maximum value & 5018 & Chekmagushevsky district \\
\hline \multirow{2}{*}{$\begin{array}{c}\text { IV } \\
\text { cluster }\end{array}$} & minimum value e & 476 & Ufimsky district \\
\hline & maximum value & 3729 & Sterlitamaksky district \\
\hline \multicolumn{4}{|c|}{ production of vegetables per capita per year, $\mathrm{kg}$} \\
\hline \multirow{2}{*}{$\begin{array}{c}\text { I } \\
\text { cluster }\end{array}$} & minimum value & 33 & Baymaksky district \\
\hline & maximum value & 151 & Belokataysky district \\
\hline \multirow{2}{*}{$\begin{array}{c}\text { II } \\
\text { cluster }\end{array}$} & minimum value & 34 & Beloretsky district \\
\hline & maximum value & 294 & Chishminsky district \\
\hline \multirow{2}{*}{$\begin{array}{c}\text { III } \\
\text { cluster }\end{array}$} & minimum value & 59 & Baltachevsky district \\
\hline & maximum value & 230 & Kushnarenkovsky district \\
\hline \multirow{2}{*}{$\begin{array}{c}\text { IV } \\
\text { cluster }\end{array}$} & minimum value & 264 & Sterlitamaksky district \\
\hline & maximum value & 351 & Ufimsky district \\
\hline \multicolumn{4}{|c|}{ Potato production per capita per year, kg } \\
\hline \multirow{2}{*}{$\begin{array}{c}\text { I } \\
\text { cluster }\end{array}$} & minimum value & 263 & Baymaksky district \\
\hline & maximum value & 672 & Kiginsky district \\
\hline \multirow{2}{*}{$\begin{array}{c}\text { II } \\
\text { cluster }\end{array}$} & minimum value & 274 & Belebeevsky district \\
\hline & maximum value & 839 & Gafuriysky district \\
\hline \multirow{2}{*}{$\begin{array}{c}\text { III } \\
\text { cluster }\end{array}$} & minimum value & 513 & Ilishevsky district \\
\hline & maximum value & 925 & Krasnokamsky district \\
\hline \multirow{2}{*}{$\begin{array}{c}\text { IV } \\
\text { cluster }\end{array}$} & minimum value & 568 & Ufimsky district \\
\hline & maximum value & 912 & Sterlitamaksky district \\
\hline
\end{tabular}

TABLE III. EXTREME VALUES OF INDICATORS OF LIVESTOCK PRODUCTION FOR FORMED CLUSTERS

\begin{tabular}{|c|c|c|c|}
\hline $\begin{array}{l}\text { Cluster } \\
\text { number }\end{array}$ & \multicolumn{2}{|c|}{ Indicators } & $\begin{array}{c}\text { Municipal } \\
\text { entity }\end{array}$ \\
\hline \multicolumn{4}{|c|}{ Production of milk per capita per year, $\mathrm{kg}$} \\
\hline \multirow{2}{*}{$\begin{array}{c}\text { I } \\
\text { cluster }\end{array}$} & minimum value & 211 & Blagoveshchensky district \\
\hline & maximum value & 1580 & Zianchurinsky district \\
\hline \multirow{2}{*}{$\begin{array}{c}\text { II } \\
\text { cluster }\end{array}$} & minimum value & 197 & Belebeevsky district \\
\hline & maximum value & 897 & Dyurtyulinsky district \\
\hline \multirow{2}{*}{$\begin{array}{c}\text { III } \\
\text { cluster }\end{array}$} & minimum value & 807 & Blagovarsky district \\
\hline & maximum value & 1981 & Chekmagushevsky district \\
\hline \multirow{2}{*}{$\begin{array}{c}\text { IV } \\
\text { cluster }\end{array}$} & minimum value & 292 & Ufimsky district \\
\hline & maximum value & 1701 & Sterlitamaksky district \\
\hline \multicolumn{4}{|c|}{ Production of meat per capita per year, kg } \\
\hline \multirow{2}{*}{$\begin{array}{c}\text { I } \\
\text { cluster }\end{array}$} & minimum value & 80 & Davlekanovskyi district \\
\hline & maximum value & 303 & Meleuzovsky district \\
\hline \multirow{2}{*}{$\begin{array}{c}\text { II } \\
\text { cluster }\end{array}$} & minimum value & 29 & Belebeevsky district \\
\hline & maximum value & 95 & Gafuriysky district \\
\hline \multirow{2}{*}{$\begin{array}{c}\text { III } \\
\text { cluster }\end{array}$} & minimum value & 86 & Kushnarenkovsky district \\
\hline & maximum value & 378 & Blagovarsky district \\
\hline \multirow{2}{*}{$\begin{array}{c}\text { IV } \\
\text { cluster }\end{array}$} & minimum value & 160 & Sterlitamaksky district \\
\hline & maximum value & 313 & Ufimsky district \\
\hline \multicolumn{4}{|c|}{ Production of eggs per capita per year, pcs. } \\
\hline \multirow{2}{*}{$\begin{array}{c}\text { I } \\
\text { cluster }\end{array}$} & minimum value & 62 & Blagoveshchensky district \\
\hline & maximum value & 863 & Alcheyevsky district \\
\hline \multirow{2}{*}{$\begin{array}{c}\text { II } \\
\text { cluster }\end{array}$} & minimum value & 55 & Ishimbaysky district \\
\hline & maximum value & 1010 & Tuimazinsky district \\
\hline \multirow{2}{*}{$\begin{array}{c}\text { III } \\
\text { cluster }\end{array}$} & minimum value & 168 & Duvansky district \\
\hline & maximum value & 463 & Blagovarsky district \\
\hline \multirow{2}{*}{$\begin{array}{c}\text { IV } \\
\text { cluster }\end{array}$} & minimum value & 4521 & Sterlitamaksky district \\
\hline & maximum value & 4956 & Ufimsky district \\
\hline
\end{tabular}

At the expense of stimulating the development of individual municipalities, the grouped agro-food clusters determine the processes of optimization of the spatial organization of the rural area and contribute to increasing the food security of the population.

It should be noted that the formation of clusters allows solving the problem of effective development not only of the agro-food complex, but also will help to ensure the multiplication of positive trends in other sectors of the economy. The economic and social contribution of each component of the cluster to increasing its competitiveness provides a certain multiplier effect (fig. 2).

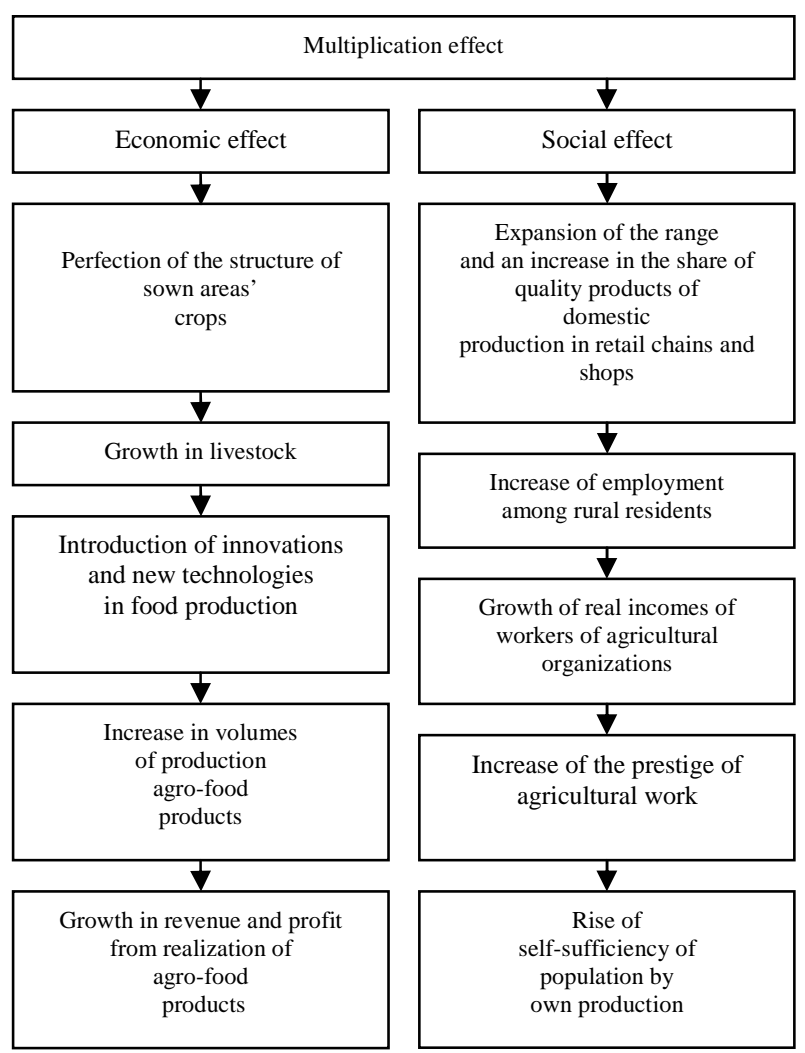

Fig. 2. The multiplication effect arising on the basis of the use of methods of cluster analysis

Analysis of clustering results showed that the municipalities of the region have different degrees of differentiation in the production of certain types of agro-food products. The specific character of the production of agro-food products directly affects the formation of the structure of cluster formations. As a result of clustering, "standard" ("leaders") and "target" ("outsiders") municipal entities for the production of agro-food products are defined. "Sample" municipal entities, as regional "cluster growth points," are a key reference point for the development of the agro-food complex.

In strategic terms, "cluster growth points" are leading agricultural organizations that can be competitive in the republican food market and are able to produce high-quality food products. The development of these enterprises will have a positive effect on other organizations involved in the processing and sale of agro-food products. At the same time, the active involvement of agro-food clusters of the leading peasant (farmer) economies of the republic should be an important task in carrying out the cluster policy of the republican authorities.

Highlighting the strengths and advantages of the "reference" municipal formations makes it possible to assess the prospective volumes of food production within their 
municipal boundaries. In the medium and long term, they should become "sources" for the development of the entire agrarian sector of the economy of the Republic.

In turn, "target" municipal formations are characterized by an extensive level of development of production of agro-food products. Municipalities of this type are depressive and crisisprone with regard to the self-sufficiency of the urban and rural population of the republic with the main types of food. The study of weaknesses and shortcomings of "targeted" municipal entities is aimed at highlighting systemic problems and evaluating their prospects for food production using strategic planning methods.

Undoubtedly, clusters are one of the most effective forms of integration, which, due to the achievement of the multiplier effect, will ensure the comprehensive development of the agro-food complex of the region. The use of the cluster approach makes it possible to assess the existing production potential of the industries associated with the agro-food market.

\section{CONCLUSION}

Thus, the use of the cluster approach helps to ensure effective management of the regional food supply to the population and the optimal placement of food production directly within the municipalities. Clusters, which will be one of the most important elements of the new "frame" structure of the agricultural sector of the economy of the Republic, should become an effective tool for overcoming the negative factors hampering the development of the agro-food complex.

It is important to emphasize that clusterization allows forming those strategic directions for the production of agrofood products which will be a priority for each specific municipal entity in the region. The use of the cluster approach in the design of the strategy for the development of the agrofood complex determines the implementation and adoption of strategically and tactically scientifically proven decisions in the system of "municipal formation - region" by the principle of "from the present to the future".

The results of the research help to propose the project of the roadmap timeline for implementing the cluster policy of development of municipalities of the Republic of Bashkortostan from the standpoint of self-sufficiency of the population with agro-food products. The methodological approaches on the use of cluster analysis methods in the strategy of the agro-food complex development of the Republic of Bashkortostan proposed in this article can be used to develop strategic programs of the agro-food complex of other territorial entities of the Russian Federation.

\section{References}

[1] E.V. Stovba, A.T. Abdrashitova, "Application of optimization modeling methods in forecasting the development of the agrofood sector in rural areas", Izvestiya Vysshikh Uchebnykh Zavedenii, Series: Economics, Finance and Production Management, vol. 3, pp. 80-89, 2013.

[2] E.V. Stovba, A.V. Stovba, "The role of innovation in strategic planning for the development of the agro-food complex of the region", Economics: yesterday, today, tomorrow, vol. 6, pp. 123-134, 2016.
[3] RF Government Order No. 1662-r of 17 November 2008 "On the Concept of Long-Term Social and Economic Development of the Russian Federation for the Period to 2020", Access mode: http://base.garant.ru/194365.

[4] Ch. Bender, R. Harms, G. Rinderman, Du clusters matter? Empirical evidence from Germany, Vniv. of Muenster, 1999.

[5] E. Feser, M. Luger, "Cluster analysis as a mode of inquiry: its use in science and technology policy-making in North Carolina", European planning studies, vol. 11, pp. 11-24, 2003.

[6] G. Christensen, "The past and future of competitive advantage", Mit sloan management review, vol. 2, pp. 10-109, 2001.

[7] R. Brown, Cluster dynamics in theory and practice with application to Scotland, Glasgow, 2000.

[8] L. Paija, The Finnish ICT cluster in the digital economy, Helsinki, 2001.

[9] A.Sh. Khuazheva, N.P. Ketova, The mechanism of sustainable development of the regional agro-industrial complex: conceptual justification, the formation of territorial-sectoral clusters, the conditions for implementation, Rostov-on-Don: Publishing house "Assistance XXI century", 2012, 288 p.

[10] Innobarometer on cluster's role in facilitating innovation in Europe. Analytical Report, The Gallup Organization Hungary, 2006, 125 p. (Access mode: http://cordis.europa.eu/innovation/en/policy/ innobarometer.htm)

[11] A.E. Romanov, V.P. Arashukov, Agro-industrial clusters: theory and practice, Tula: Grif and K, 2009, 142 p.

[12] The use of the cluster approach in the modernization of the economic space of the Russian Federation, Ed. A.I. Tatarkin, Ekaterinburg: Institute of Economics, UrB RAS, 2013, 559 p.

[13] Agrarian Europe in the 21st century, Under the general ed. E.N. Krilatykh, Moscow: Summer Garden, 2015, 328 p.

[14] O. Solvell, Clusters: Balancing Evolutionary and Constructive Forces, Stockholm: Ivory Tower Pub, 2009, 140 p.

[15] Regions of Russia. Socio-economic indicators: a statistical compilation, Moscow: Rosstat, 2016, 1326 p. 